\title{
Parapseudoleptomesochra phayaoensis, a new species of copepod (Copepoda: Harpacticoida: Ameiridae) from a cave in northern Thailand
}

\author{
Kamonwan Koompoot ${ }^{1}$, La-orsri Sanoamuang ${ }^{1,2^{*}}$ \\ ${ }^{I}$ Applied Taxonomic Research Center, Department of Biology, Faculty of Science, \\ Khon Kaen University, Khon Kaen 40002, Thailand. \\ ${ }^{2}$ International College, Khon Kaen University, Khon Kaen 40002, Thailand. \\ "Corresponding author: la_orsri@kku.ac.th
}

ABSTRACT: A new species of freshwater harpacticoid copepod, Parapseudoleptomesochra phayaoensis sp.n., was found in a sample collected from a cave in northern Thailand. The new species resembles $P$. italica Pesce et Petkovski, 1980; however, it differs from $P$. italica by (1) the armature of baseoendopod and exopod of the fifth leg in both sexes, (2) the setal formula on P1 Exp-3 and P3-P4 Enp-3 and (3) by having a long inner accessory seta (seta VI) on the caudal rami in the female. To our knowledge, this is the first species of the genus Parapseudoleptomesochra Lang, 1965 described in Southeast Asia.

How to cite this article: Koompoot K., Sanoamuang L. 2021. Parapseudoleptomesochra phayaoensis, a new species of copepod (Copepoda: Harpacticoida: Ameiridae) from a cave in northern Thailand// Invert. Zool. Vol.18. No.1. P.1-15. doi: 10.15298/invertzool.18.1.01

KEY WORDS: cave-dwelling copepod, freshwater, karstic cave, Southeast Asia, stygobionts.

\section{Parapseudoleptomesochra phayaoensis, новый вид копепод (Copepoda: Harpacticoida: Ameiridae) из пещеры в северном Таиланде}

\author{
Камонван Коомпут ${ }^{1}$, Ла-орсри Саноамуанг $r^{1,2^{*}}$ \\ ${ }^{1}$ Applied Taxonomic Research Center, Department of Biology, Faculty of Science, Khon Kaen \\ University, Khon Kaen 40002, Thailand. \\ ${ }^{2}$ International College, Khon Kaen University, Khon Kaen 40002, Thailand. \\ "Corresponding author: la_orsri@kku.ac.th
}

РЕЗЮМЕ. Новый вид пресноводных гарпактикоидных копепод Parapseudoleptomesochra phayaoensis sp.n. обнаружен в пробе из пещеры на севере Таиланда. Новый вид наиболее близок к виду P. italica Pesce et Petkovski, 1980 и отличается него (1) вооружением базоэндоподита и экзоподита пятой ноги у обоих полов, (2) формулой вооружения дистального членика экзоподита первой плавательной ноги и дистального членика эндоподита третьей и четвертой плавательных ног и (3) наличием длинной внутренней добавочной щетинки (щетинка VI) на каудальных ветвях самки. Данное описание - первая находка представителя рода Parapseudoleptomesochra Lang, 1965 в Юго-восточной Азии. 
Как цитировать эту статью: Koompoot K., Sanoamuang L. 2021. Parapseudoleptomesochra phayaoensis, a new species of copepod (Copepoda: Harpacticoida: Ameiridae) from a cave in northern Thailand // Invert. Zool. Vol.18. No.1. P.1-15. doi: 10.15298/invertzool.18.1.01

КЛЮЧЕВЫЕ СЛОВА. Пещерные веслоногие ракообразные, пресноводные водоемы, карстовые пещеры, Юго-восточная Азия, стигобионты.

\section{Introduction}

The hypogean Parapseudoleptomesochra Lang, 1965, is a diverse genus of the family Ameiridae Monard, 1927.Despite being of marine origin, this genus has successfully colonized freshwater and groundwater habitats, such as springs, wells, and caves (Rao, 1972; Kunz, 1975; Pesce, 1981; Dumont, 1984; Rouch, 1986; Boxshall, Halsey, 2004; Karanovic, 2006; Boxshall, Defaye, 2008).

The genus Parapseudoleptomesochra was established by Lang (1965) to include the marine species Ameira trisetosa Krishnaswamy, 1957 from the coast of Madras. The genus Parapseudoleptomesochra differed from other ameirid genera by their 3-segmented endopods on P2-P4; other characters have not been considered (Lang, 1965; Petkovski, 1976). Pesce and Petkovski (1980) emended the generic diagnosis of the genus Parapseudoleptomesochra to include information about the segmentation of the swimming legs (P1-P4 with 3-segmented exopod and endopod), the presence or absence of an inner seta on P1 Exp-2, the absence of inner seta in P2-P4 Exp-1, the presence or absence of an inner seta on P2-P4 End-2, and the presence of two outer spines in P2-P4 Exp3. Mielke (1995) considered that the genus Parapseudoleptomesochra, as characterized by Pesce \& Petkovski (1980), did not represent a monophyletic taxon and most characters were considered plesiomorphic. He interpreted the absence of inner seta in P2-P4 Exp-1 and the presence of two outer spines in P3-P4 Exp-3 as apomorphies. Moreover, he proposed that specimens of $P$. trisetosa (Krisnaswamy, 1957) from the Caribbean coast of Venezuela were conspecific with those from the type locality of Madras, although his specimens clearly differ from the original description of $P$. trisetosa by Krisnaswamy (1957). Mieke's specimens differ from P. trisetosa (Krisnaswamy, 1957) by having 8 segments of antennule in the female ( 7 segments in the Indian species), bearing 1-segmented exopod on antenna (2-segmented in the Indian species), the P1 Enp-3 with 3 setae (2 setae in the Indian species), the P3 Enp-3 with 2 setae (only 1 seta in the Indian species), the presence of 4 setae on the female baseoendopod ( 3 setae in the Indian species), the presence of 2 setae on the male baseoendopod (only 1 seta in the Indian species).

Currently, 28 species and subspecies have been recognized in the genus Parapseudoleptomesochra Lang, 1965. These species are widely distributed across Africa, Asia, Australia, Europe, and North America, but information on this genus is lacking from Southeast Asia (Karanovic, 2004, 2006; Wells, 2007). Most of the species of the genus Parapseudoleptomesochra can be found in subterranean habitats such as the hyporheic zones, springs, and other types of groundwater environments (Pesce, 2016).

In Southeast Asia, approximately 42 species of groundwater copepods belong to the genera Asiacaris Cottarelli, Bruno et Berera, 2010, Attheyella Brady, 1880, Boholina Fosshagen et Iliffe, 1989, Bryocyclops Kiefer, 1927, Elaphoidella Chappuis, 1929, Epactophanes Mrázek, 1893, Fierscyclops Karanovic, 2004, Hadodiaptomus Brancelj, 2005, Kinnecaris Jakobi, 1972, Nitokra Boeck, 1865, Onychocamptus Daday, 1903, Parastenocaris Kessler, 1913, and Phyllognathopus Mrázek, 1893. Most of the species are recorded from Thailand, and have been collected from epikarstic habitats (Brancelj et al., 2010, 2013; Watiroyram et al., 2012; Watiroyram et al., 2015a, b, 2017; Watiroyram, Brancelj, 2016; Karanovic et al., 2017, 
Boonyanusith et al., 2018; Watiroyram, 2018a, b). However, no representative of the genus Parapseudoleptomesochra has been reported from Thailand. During our investigation of cavedwelling copepods in northern Thailand, the first record of the genus Parapseudoleptomesochra is herein presented and a new species of this genus from the Chom Sin cave, Phayao Province, northern Thailand is described.

\section{Materials and methods}

Qualitative samples were collected from pools on the floor of Chom Sin cave in Phayao Province, northern Thailand, from July 2015 to June 2016 using a $30 \mu \mathrm{m}$ mesh hand net. The concentrated samples were directly preserved in $4 \%$ formalin. The samples were transferred to pure glycerol and dissected at 100x using an Olympus SZ40 stereomicroscope. For illustrations, the habitus and dissected appendages were drawn at 400x and 1000x with the aid of a drawing tube mounted to an Olympus CH30 compound microscope. The CorelDRAW Graphics Suite 2017 program was employed for the final version of the illustrated figures. Specimens for a scanning electron microscopy (SEM) were dehydrated in graded ethanol concentrations, and then transferred to pure isoamyl acetate. The specimens were placed in a criticalpoint apparatus for drying. Dried specimens were mounted on stubs and coated with gold. The descriptive terminology follows Huys \& Boxshall (1991). Abbreviations used in the text are: End - endopod; Exp - exopod; Exp (End)-1 $(2,3)$ to denote the proximal (middle, distal) segment; ae - aesthetasc; P1-P6 - first to sixth thoracic appendages. The type material is deposited at the Natural History Museum (NHMUK) of London, United Kingdom.

\section{Taxonomic account}

Order Harpacticoida Sars, 1903

Family Ameiridae Monard, 1927

Genus Parapseudoleptomesochra Lang, 1965 Parapseudoleptomesochra phayaoensis sp.n. Figs. 1-8.
ETYMOLOGY. The specific name phayaoensis is taken after the type locality, Phayao Province. The name is with the Latin suffix "-ensis", which refers to the type locality.

TYPE LOCALITY. Chom Sin cave, Ban Tham Subdistrict, Dok Kham Tai District, Phayao Province, Northern Thailand $\left(19^{\circ} 04^{\prime}\right.$ $\left.52.68^{\prime \prime} \mathrm{N}, 100^{\circ} 04^{\prime} 24.74^{\prime \prime} \mathrm{E}\right), 443 \mathrm{~m}$ above sea level. The cave is about $15 \mathrm{~m}$ long, with one single horizontal gallery. Most of the cave is completely dark with little airflow. A pool filled with percolating water about $4 \mathrm{~m}$ in diameter, is located in the inner part of the cave, and is not connected to any surface water. On the collecting date (10 June 2016), the following water parameters were measured: temperature $26.6^{\circ} \mathrm{C}$, $\mathrm{pH} 7.3$, a conductivity of $639.3 \mu \mathrm{S} \mathrm{cm} \mathrm{cm}^{-1}$, dissolved oxygen $4.7 \mathrm{mg} \mathrm{L}^{-1}$, nitrate concentration $1.1 \mathrm{mg} \mathrm{L}^{-1}$ and orthophosphate concentration $0.56 \mathrm{mg} \mathrm{L}^{-1}$.

MATERIAL EXAMINED. Holotype: one adult female (NHMUK 1009), dissected and mounted in glycerol on one slide; allotype, one adult male (NHMUK 1010), dissected and mounted in glycerol on one slide; paratypes, eleven adult females (NHMUK1011-1021), undissected and preserved in $70 \%$ ethanol in a $1.5 \mathrm{~mL}$ microtube. All specimens were collected on 10 June 2016 by K. Koompoot.

DESCRIPTION OF FEMALE. Body length (measured from anterior margin of rostrum to posterior of caudal rami, excluding caudal setae), 575-609 $\mu \mathrm{m}(\mathrm{n}=5$; mean $=591 \mu \mathrm{m})$, fusiform (Fig. 1A-C). Prosome/urosome ratio 1.8 with largest width along posterior margin of cephalothorax. Naupliar eye not discernible. Rostral tip short and small. Cephalothorax nearly ovoid on lateral view, proportional length/ width cephalothorax about 1.0. Integument of cephalic shield bearing several pairs of sensilla on dorsal surface (Fig. 1D, E). Posterior margin of prosomites smooth dorsally (Fig. 1F).

Fifth pedigerous somite, thoracic somite (Fig. 2A) with serrated posterior margin, ornamented with transverse rows of tiny spinules on lateral view. Genital double-somite (Fig. 2A) 0.6 times as long as wide, with short rows of minute spinules laterally on proximal half 


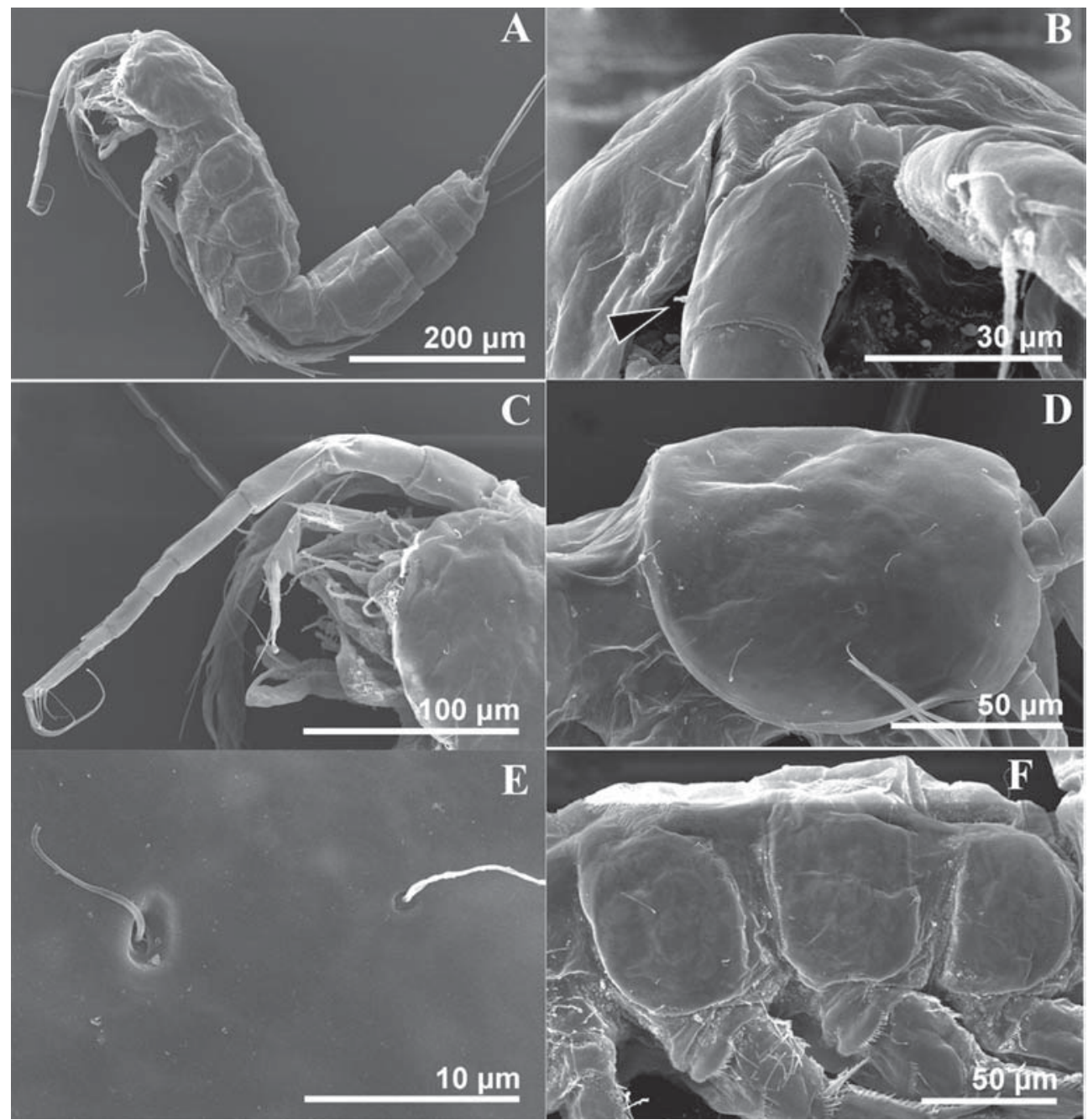

Fig. 1. Parapseudoleptomesochra phayaoensis sp.n., SEM photographs, female: A - habitus, lateral view; $\mathrm{B}$ - rostral area of cephalothorax, ventroanterior view (arrow indicates a cuticular tube); C - frontal part of cephalothorax with appendages, lateral view; D - cephalothorax, lateral view; E - two sensilla on cephalothorax; F - tergites of free prosomites with coxa and basis of P2-P4.

Рис. 1. Parapseudoleptomesochra phayaoensis sp.n., СЭМ, самка: А - вид сбоку; В - ростральная область головогруди, передневентрально (стрелка указывает на кутикулярную трубку); C - фронтальная часть головогруди с конечностями, вид сбоку; D - головогрудь, вид сбоку; Е - две сенсиллы на головогруди; F - тергиты свободных сегментов просомы с коксой и базисом ног 1-4.

and a transverse row above its posterior margin, hyaline fringe serrated on posterior margin. Genital complex with single copulatory pore, seminal receptacles curve and strongly sclerotized. P6 reduced, fused into a small plate on each side of copulatory pore, without armature (Fig. 5A). Urosomites 3-4 with a continuous row of minute spinules above posterior margins; with serrated hyaline frills on posterior margins (Figs 2B-D, 5A). Anal somite (Figs 2E, F, 5A, B) with short row of spinules on dorsal surface; posterior margin consisting of prominent spinules on dorsal, lateral and ventral views. 


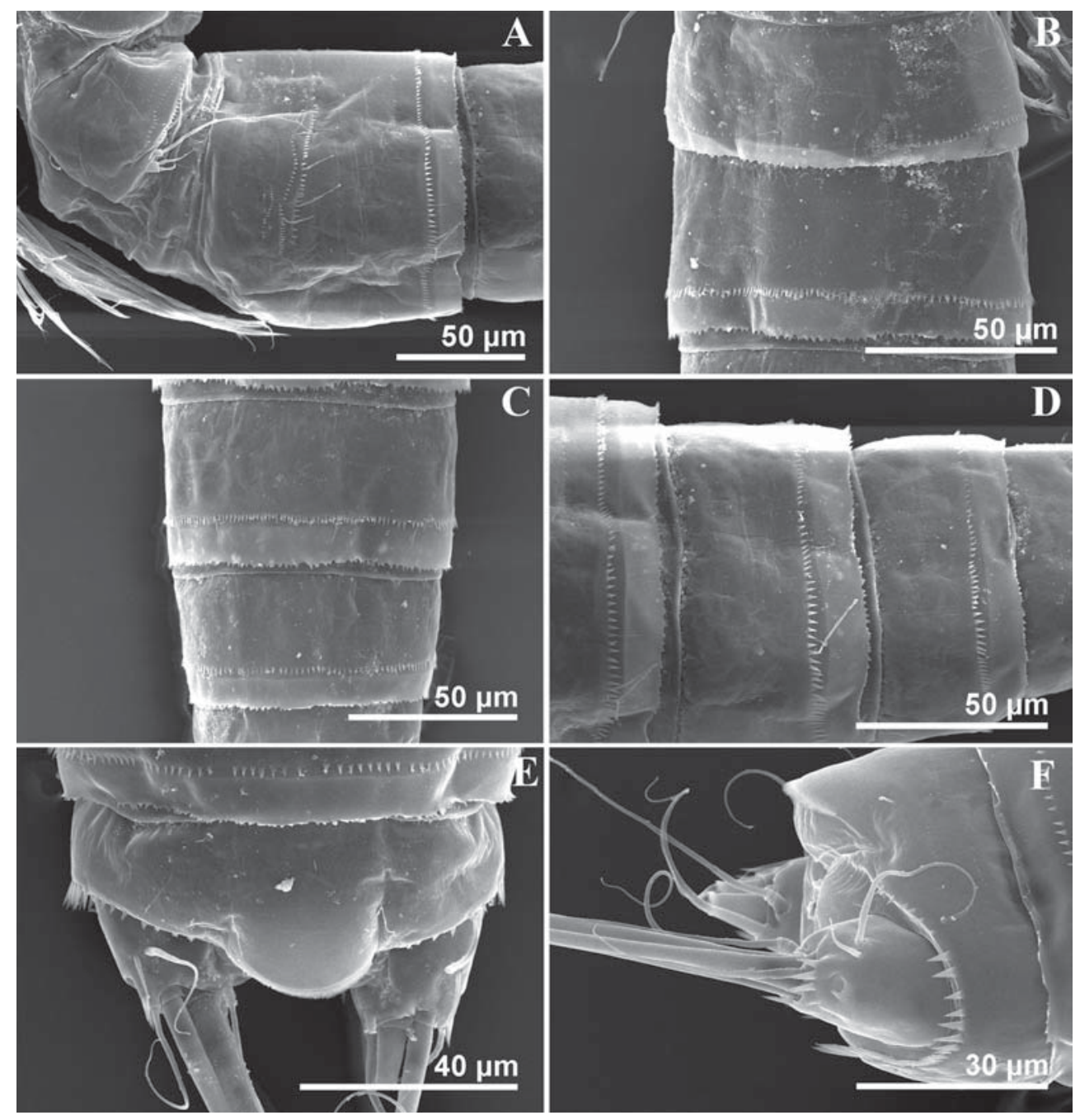

Fig. 2. Parapseudoleptomesochra phayaoensis sp.n., SEM photographs, female: $\mathrm{A}-5^{\text {th }}$ pedigerous somite and genital double-somite, lateral view; $\mathrm{B}-2^{\text {nd }}$ (genital) and $3^{\text {rd }}$ urosomites, dorsal view; $\mathrm{C}-4^{\text {th }}$ and $5^{\text {th }}$ urosomites, dorsal view; $\mathrm{D}-4^{\text {th }}$ and $5^{\text {th }}$ urosomites, lateral view; $\mathrm{E}$ - anal somite and caudal rami, dorsal view; $\mathrm{F}$ - anal somite and caudal rami, lateral view.

Рис. 2. Parapseudoleptomesochra phayaoensis sp.n., СЭМ, самка: А - сегмент с 5-й парой ног и генитальный двойной сегмент, вид сбоку; В - 2-й (генитальный) и 3-й сегменты уросомы, вид сверху; C - 4-й и 5-й сегменты уросомы, вид сверху; D-4-й и 5-й сегменты уросомы, вид сбоку; $\mathrm{E}$ - анальный сегмент и каудальные ветви, вид сверху; F - анальный сегмент и каудальные ветви, вид сбоку.

Anal operculum (Figs 2E, F, 5B) convex, reaching beyond somite, with frill on its margin.

Caudal rami (Figs 2E-F, 3A, 5A, B) subconical, about 1.2 times as long as wide, slightly divergent, armed with seven elements. Armature consists of one short anterolateral external accessory seta (seta I) and a long anterolateral external seta (seta II). Posterolateral seta (seta III) about 1.9 times as long as caudal ramus, with three large spinules at base of distal posterolateral seta. Outer terminal seta (seta IV) without breaking plane, pinnate at distal end, 


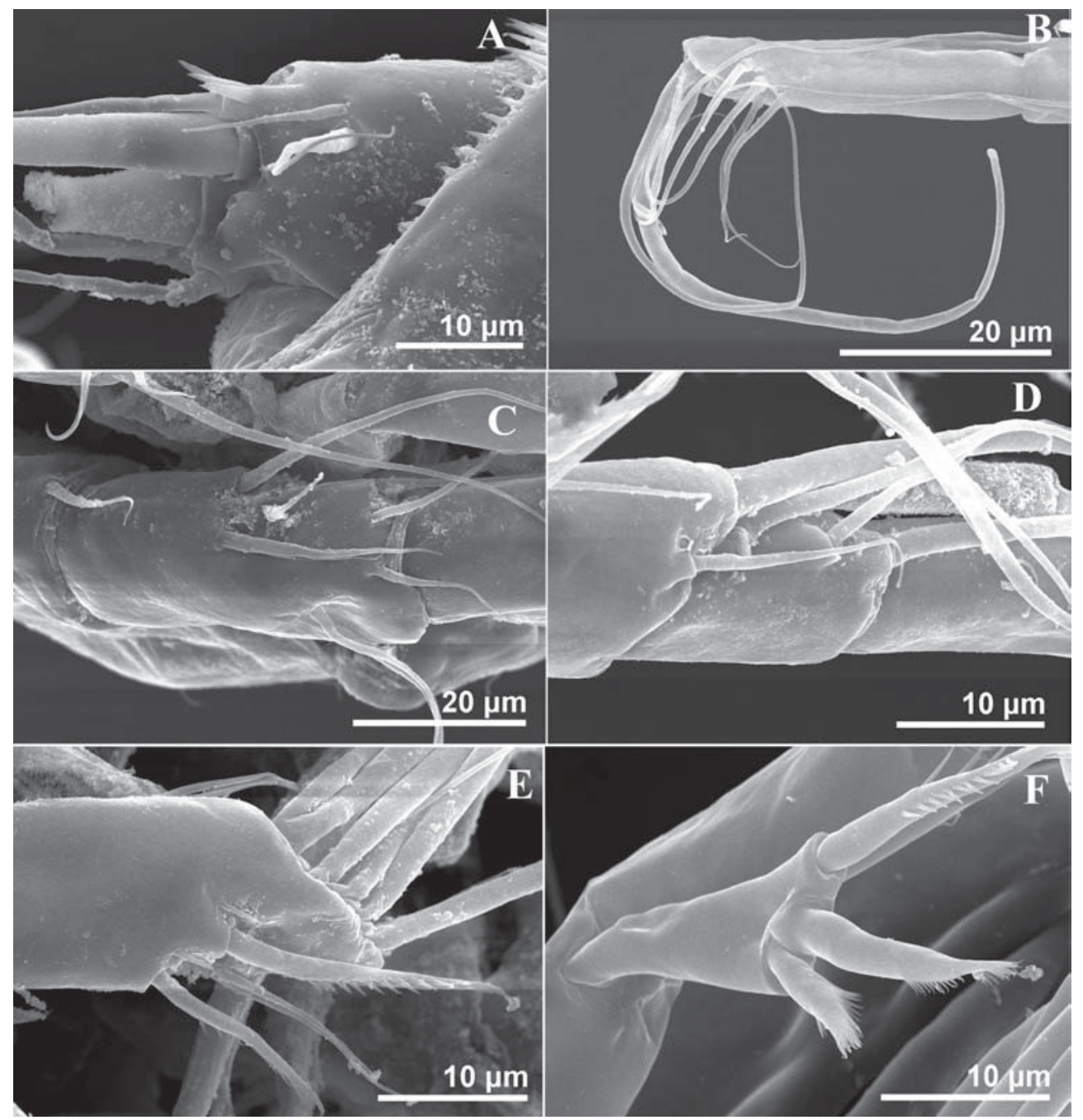

Fig. 3. Parapseudoleptomesochra phayaoensis sp.n., SEM photographs, female: A - left caudal ramus, dorsal view; B - last two segments of antennule, lateral view; C - first two segments of antennule, anterior view; D $-4^{\text {th }}$ to $6^{\text {th }}$ segments of antennule, anterior view; E - distal tip of antennal endopod, anterior view; F - Exp of antenna, lateral view.

Рис. 3. Parapseudoleptomesochra phayaoensis sp.n., СЭМ, самка: А - левая каудальная ветвь, вид сверху; В - два дистальных членика антеннул, вид сбоку; С - два проксимальных членика антеннул, вид спереди; D - 4-6-й членики антеннул, вид спереди; Е — дистальный отдел эндоподита антеннул, вид спереди; F — экзоподит антенны, вид сбоку.

about 3.7 times as long as caudal ramus. Inner terminal seta (seta $\mathrm{V}$ ) slightly enlarged base and relatively long, without breaking plane, pinnate at distal end, about 20 times as long as caudal ramus. Inner accessory seta (seta VI) smooth, about 2.4 times as long as caudal ramus. Dorsal seta (seta VII) articulated, arising near posterior inner edge, about 3.7 times as long as caudal ramus.

Antennule (Figs. 3B-D, 6A) eight-segmented and elongate, longer than cephalothorax. Aesthetasc on fourth segment not reaching be- 


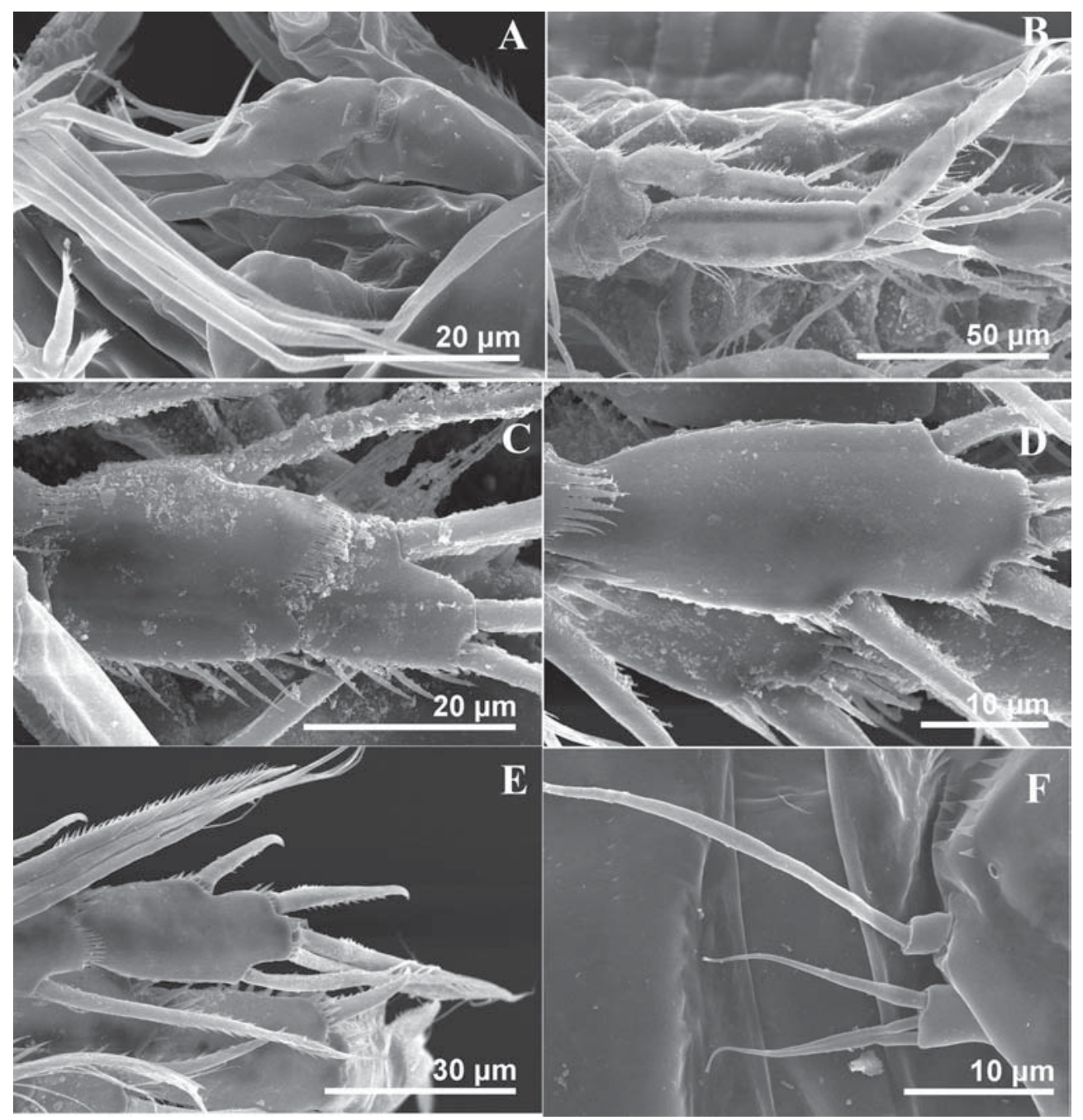

Fig. 4. Parapseudoleptomesochra phayaoensis sp.n., SEM photographs, female: A - mouth appendages, lateral view; B - P1, anterior; C - P2 Enp, anterior view; D - P2 Exp-3, anterior view; E - P3 Exp-3, anterior view; $\mathrm{F}-\mathrm{P}$ 5, lateral view.

Рис. 4. Parapseudoleptomesochra phayaoensis sp.n., СЭМ, самка: А - околоротовые конечности, вид сбоку; В - нога 1, вид сбоку; С - вид спереди; D - дистальный членик экзоподита 2-й ноги; Е дистальный членик экзоподита 3-й ноги, вид спереди; F - нога 5, вид сбоку.

yond tip of last segment. Setal formula: I (1), II (9), III (5), IV (2, 1+ae), V (4). VI (2), VII (5), VIII (6). Segment 1 with one smooth seta and row of spinules, with cuticular tube on anterior surface (Fig. 1B).

Antenna (Figs 3E, F, 6B) composed allobasis, two-segmented Enp and one-segmented Exp. Allobasis unarmed, about 1.5 times as long as wide, with row of spinules along outer margin. Enp-1 about 2.8 times as long as wide, unarmed and unornamented. Enp-2 with nine elements: with two surface frills subdistally, armed laterally with two pinnate spines and one slender seta; ornamentation consist of two large spinules distally on anterior surface, apical armature consisting of five geniculate setae, longest one 


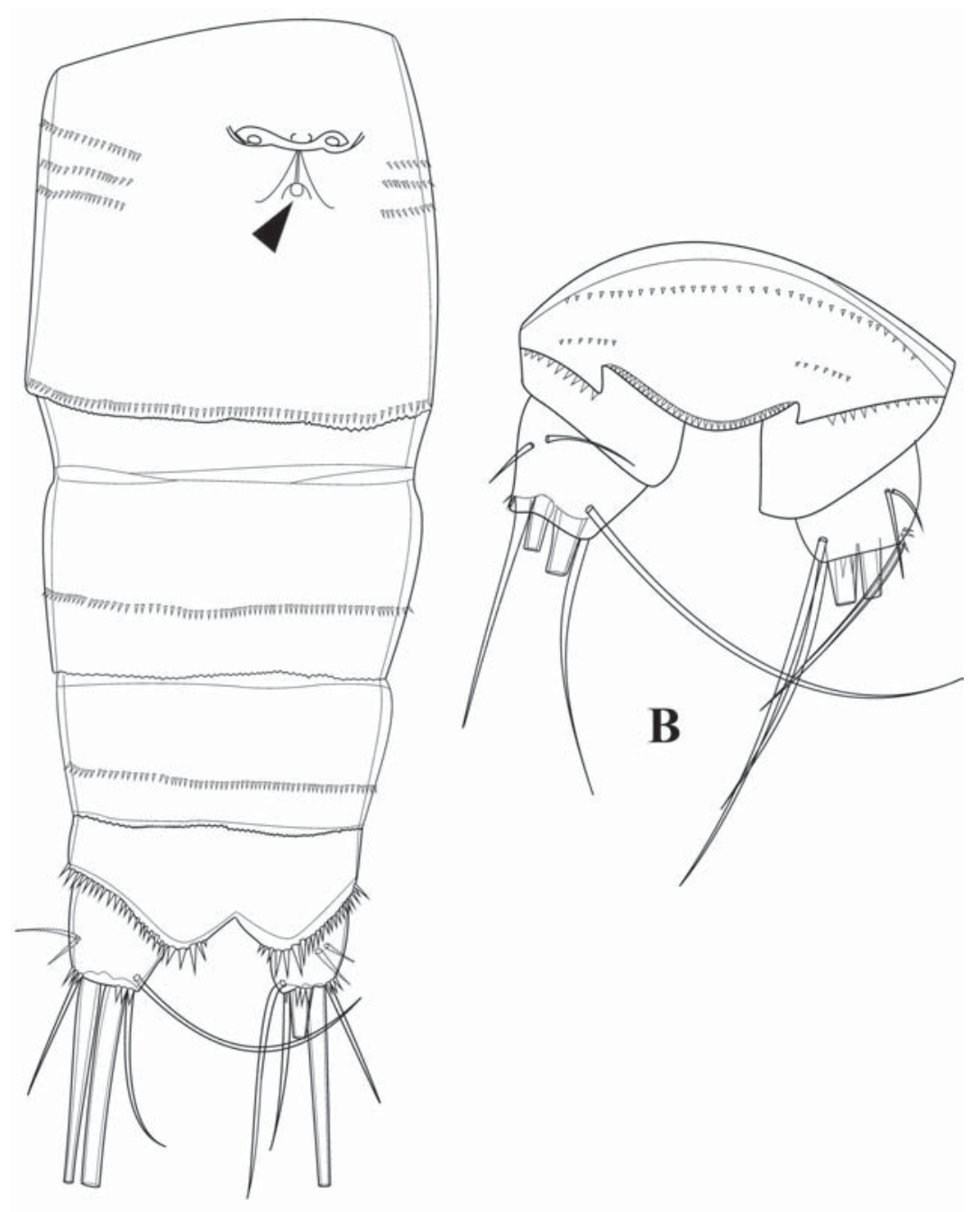

A

\begin{abstract}
A, B
Fig. 5. Parapseudoleptomesochra phayaoensis sp.n., female (holotype): A — urosomites 2-5 with caudal rami, ventral view (arrow indicates a copulatory pore); B - caudal rami, dorsal view. Scale bar $0.1 \mathrm{~mm}$. Рис. 5. Parapseudoleptomesochra phayaoensis sp.n., самка (голотип): А - сегменты уросомы 2-5 с каудальными ветвями, вид снизу (стрелка указывает на копулятивную пору); В — каудальные ветви, вид сверху. Масштаб 0,1 мм.
\end{abstract}

fused basally to additional smaller and slender seta. Exp with three strong apical setae.

Labrum (Fig. 6C) subtriangular, well-sclerotized, ornamented with a row of teeth on distal margin.
Mandible(Fig. 6D) elongated coxa and wide based. Gnathobase robust, with three slightly curved teeth ventrally and a row of many teeth along distal edge, one unipinnate seta dorsally. Mandibular palp two-segmented, comprising 


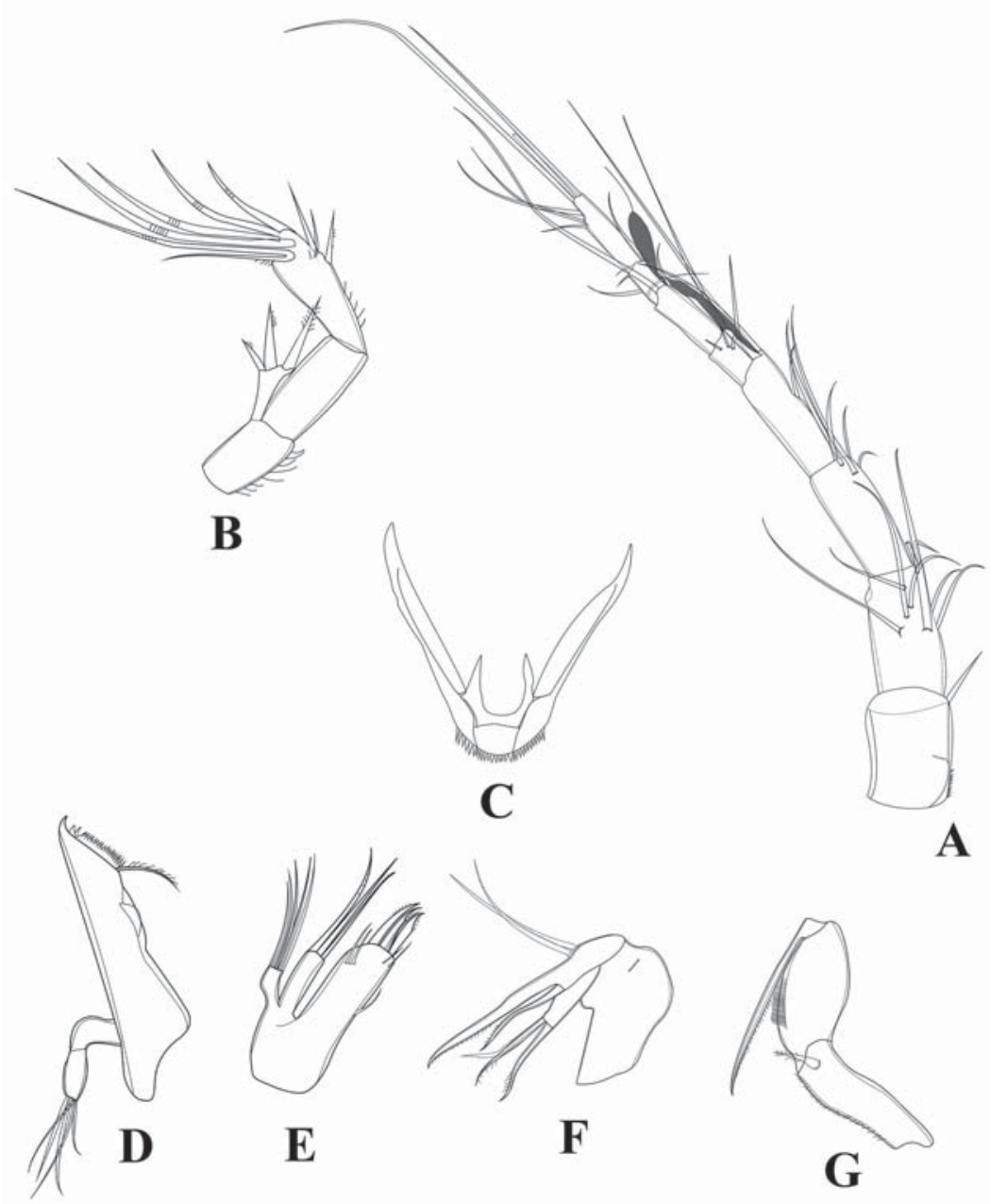

$\mathrm{A}, \mathrm{B}, \mathrm{C}, \mathrm{D}, \mathrm{E}, \mathrm{F}, \mathrm{G}$

Fig. 6. Parapseudoleptomesochra phayaoensis sp.n., female (holotype): A — antennule; B — antenna; C labrum; D - mandible; E - maxillule; F - maxilla; G - maxilliped. Scale bar $0.1 \mathrm{~mm}$.

Рис. 6. Parapseudoleptomesochra phayaoensis sp.n., самка (голотип): А — антеннула; В - антенна; C лабрум; D - мандибула; Е — максиллула; F — максилла; G — максиллипед. Масштаб 0,1 мм.

basis and one-segmented endopod. Basis unarmed and unornamented. Endopod segment slender, with five smooth setae apically.

Maxillule (Fig. 6E) with strong praecoxal arthrite and two long, smooth setae on aboral surface, two smooth setae on inner distal margin, four apical setae (three unipinnate strong setae and one smooth slender seta) and one seta proximally on oral margin. Coxal endite with three smooth setae. Basis with five smooth setae apically. Exp and Enp absent.

Maxilla (Figs 4A, 6F) composed of syncoxa, basis and one-segmented Enp. Syncoxa with row of spinules on anterior surface, prox- 


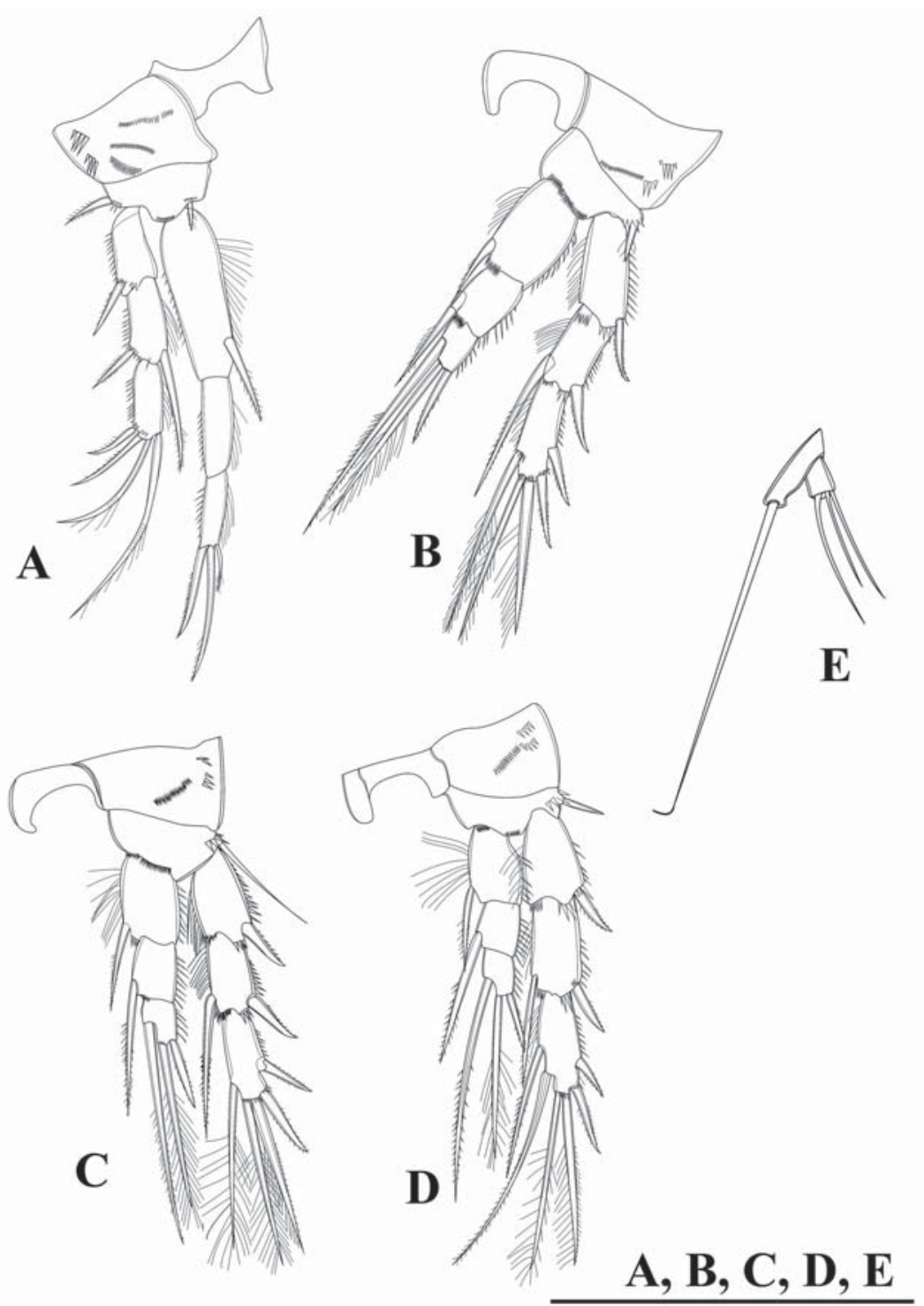

Fig. 7. Parapseudoleptomesochra phayaoensis sp.n., female (holotype): A $-\mathrm{P} 1$; B $-\mathrm{P} 2$; C $-\mathrm{P} 3$; D P4; E - P5. Scale bar $0.1 \mathrm{~mm}$.

Pис. 7. Parapseudoleptomesochra phayaoensis sp.n., самка (голотип): А - нога 1; В - нога 2; C - нога 3; D - нога 4; Е — нога 5. Масштаб 0,1 мм.

imal endite completely reduced, distal endite armed with two unipinnate spines and one smooth seta. Basis drawn out into robust unipinnate claw and one unipinate seta. Enp reduced to minute segment, with two smooth setae.

Maxilliped (Fig. 6G) comprising syncoxa, basis and one-segmented Enp. Syncoxa with row of spinules along inner margin and one pinnate seta. Basis stout, about 1.8 times as long as wide, with a row of spinules along inner median margin. Enp represented by distal unipinnate claw.

P1-P4: (Fig. 7A-D) biramous, with threesegmented Exp and Enp; Exp longer than Enp 
on P2-P4, shorter on P1. Armature of P1-P4 as follows (legend: inner/outer spine or seta; inner/ terminal/outer; Arabic numerals represent setae; Roman numerals represent spines).

\begin{tabular}{ccccccc} 
& \multicolumn{3}{c}{ Exopod } & \multicolumn{3}{c}{ Endopod } \\
& 1 & 2 & 3 & 1 & 2 & 3 \\
P1 & $0 / \mathrm{I}$ & $1 / \mathrm{I}$ & $0 / 2 / \mathrm{II}$ & $1 / 0$ & $0 / 0$ & $1 / 2 / 0$ \\
$\mathrm{P} 2$ & $0 / \mathrm{I}$ & $1 / \mathrm{I}$ & $1 / 2 / \mathrm{II}$ & $1 / 0$ & $1 / 0$ & $1 / 2 / 0$ \\
$\mathrm{P} 3$ & $0 / \mathrm{I}$ & $1 / \mathrm{I}$ & $1 / 2 / \mathrm{II}$ & $1 / 0$ & $1 / 0$ & $1 / 2 / 0$ \\
$\mathrm{P} 4$ & $0 / \mathrm{I}$ & $1 / \mathrm{I}$ & $2 / 2 / \mathrm{II}$ & $1 / 0$ & $1 / 0$ & $1 / 2 / 0$
\end{tabular}

P1 (Figs 4B, 7A) coxa; with three rows of spinules on anterior surface and two short rows of spinules on outer margin. Basis with one outer and one inner pinnate spine; row of spinules along outer distal margin, and near base of exopod. Exp-1 with one outer spine on distal margin. Exp-2 with one outer spine on distal margin and one pinnate seta at inner distal margin. Exp-3 with two strong outer spines and two apical geniculate setae. Enp-1 long, about 3 times as long as wide, extending nearly middle half of Exp-3, with one inner pinnate seta distally. Enp-2 unarmed. Enp-3 with two strong apical setae and one thin inner distal seta. All segment of exopod and endopod ornamented with small spinules and hair-like spinules along outer and inner margins, and exopodal segments also with spinules along distal margin.

P2 (Figs. 4C-D 7B) coxa; with one row of spinules on anterior surface and two short rows of spinules on outer margin. Basis with one outer spine; row of spinules along outer distal margin, and near base of endopod. Exp 1-2 with one outer spine on distal margin, Exp-2 with one additional pinnate seta at inner distal margin and an outer bipinnate spine. Exp-3 with two outer spines, two apical pinnate setae (one is spiniform), and inner pinnate seta. Enp-1-2 with inner pinnate seta at distal outer margin. Enp-3 with an inner seta and two apical setae. All segment of exopod ornamented with small spinules and hair-like spinules along outer and inner margins, and exopodal segments also with spinules along distal margin. Enp-1 ornamented with spinules and hair-like spinules along outer and inner margins. Enp-2-3 ornamented with spinules along outer and distal margins.
P3 (Figs 4E, 7C) similar to P2, except basis with slender outer seta. Enp-2 with longer inner seta, reaching to tip of outer apical seta on Enp3. All segment of exopod and endopod ornamentation similar to P2. Enp-3 with one inner pinnate seta and two apical pinnate setae.

P4 (Fig. 7D) coxa, basis and Exp similar to those in $\mathrm{P} 2$, except basis with one outer spine. Exp-3 with two outer spines, two apical pinnate setae (one is spiniform), and two inner pinnate setae. Enp-2 with a long inner seta, reaching to tip of outer apical seta on Enp-3. Enp-3 with one inner pinnate seta and two apical pinnate setae. All segment of exopod and endopod ornamentation similar to $\mathrm{P} 2$.

P5 (Figs 4F, 7E): with reduced baseoendopod, with one outer seta. Exp subquadrate, with three smooth setae; inner and outer setae subequal in length, middle seta shortest.

DESCRIPTION OF MALE.(Fig. 8A). Body length $395 \mu \mathrm{m}$ (measured from anterior margin of rostrum to apex of caudal rami, excluding caudal setae), smaller than female, habitus, general ornamentation of body somites as in female except for typical sexual dimorphism in genital segment, geniculate antennules and P1 basis.

Caudal rami (Fig. 8A) about 1.0 times as long as wide, slightly shorter than those of female. Armature and ornamentation as in female.

Antennule(Fig. 8B) geniculate, ten-segmented, aesthetasc on apical acrothek of segment 5, reaching almost tip of antennule. First segment similar to female. Setal formula as follow: I (1), II (9), III (6), IV (2), V (2+ae), VI (1), VII (1), VIII (1), IX (3), X (8). All setae smooth, except setae on second segment ornamented with one unipinnate and one pinnate and seven smooth setae. Fifth segment ornamented with three spinules on anterior surface.

Antenna, labrum, mandible, maxillule, maxilla, and maxilliped as in female.

P1-P5 (Fig. 8C-D) with same segmentation and majority of ornamentation similar to female but P1 with a modified inner basal spine (Fig. 8C).

P6 (Fig. 8A) completely fused to genital somite, with one smooth seta on each side of posterior margin. 

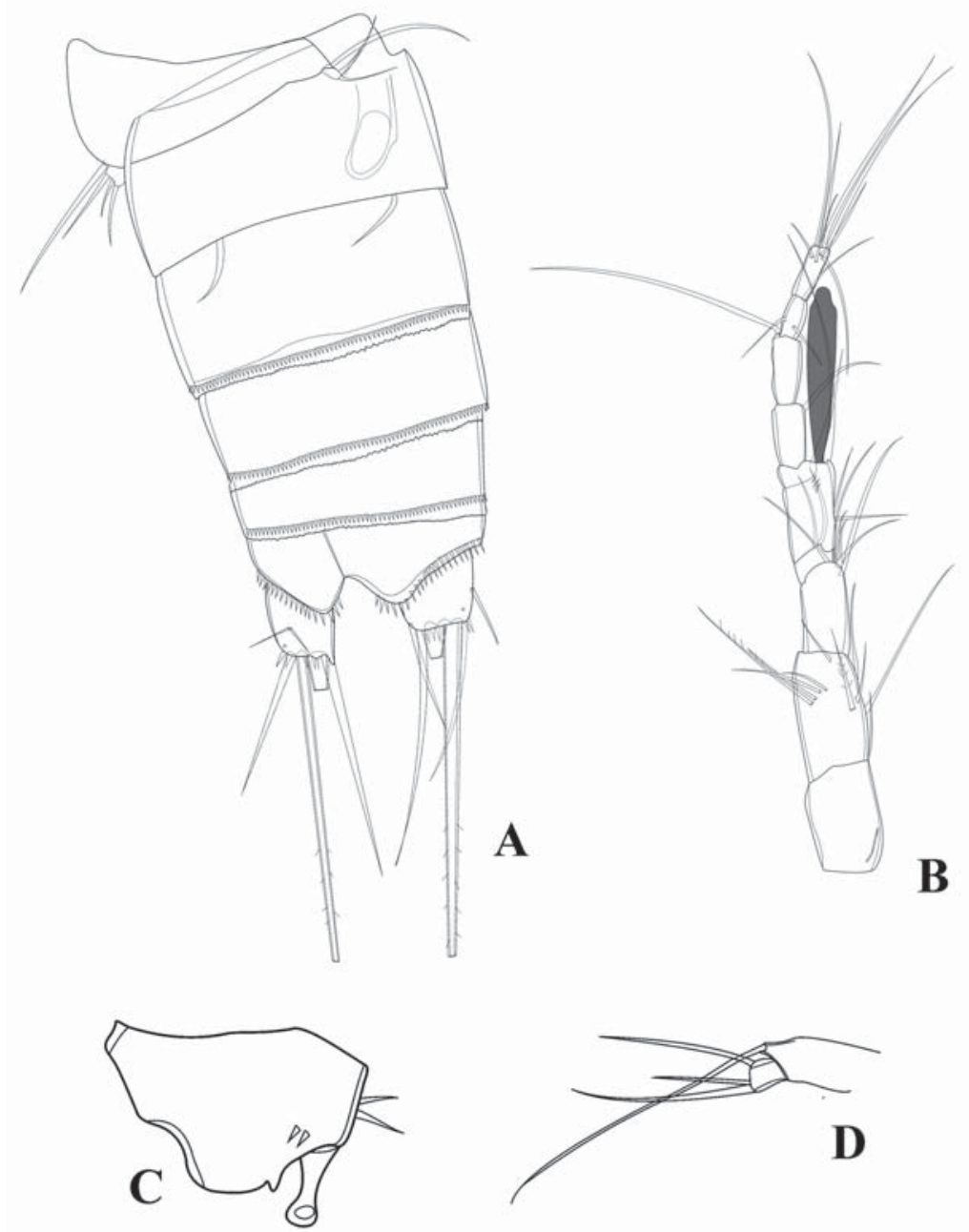

A, B, C, D

Fig. 8. Parapseudoleptomesochra phayaoensis sp.n., male (allotype): A - urosome, P5 and P6; B antennule; $\mathrm{C}$ - a modified spine on basis of P1; D - P5. Scale bar $0.1 \mathrm{~mm}$.

Рис. 8. Parapseudoleptomesochra phayaoensis sp.n., самка (аллотип): А - уросома, ноги 5 и 6; В антеннула; C - измененный шип на базисе ноги 1; D - нога 5. Масштаб 0,1 мм.

\section{Discussion}

The genus Parapseudoleptomesochra was established by designating the species Ameira trisetosa as type species. Walter \& Boxshall (2020) placed P. trisetosa in the genus Ameira, but did not provide any explanations or references. The most recent studies on the genus
Parapseudoleptomesochra agree that the species belonging to this genus share two synapomorphies i.e., there is no inner seta on the P2-P4 Exp-1, and the P3-P4 Exp-3 have two outer spines (Karanovic, 2004; Karanovic, 2006; Wells, 2007). The first character is also presented in some species of Ameira such as A. usitata Kile, 1950, A. zahaae Karanovic et Cho, 2012, 
A. kimchi Karanovic et Cho, 2012 (Lang, 1948; Petkovski, 1957; Kunz, 1975; Karanovic, Cho, 2012). It is conceivable that this character is the product of a convergence. The second character does not completely fit to $P$. dubia Kunz, 1975, which has three outer spines on P3 Exp-3. Thus, the presence of the two outer spines on P4 Exp3 is considered as a synapomorphy for all species of the genus (Pesce, Petkovski, 1980; Pesce, 1981; Dumont, 1984; Rouch, 1986; Mielke, 1995; Karanovic, 2004, 2006; Wells, 2007). This character is also present in P. trisetosa, and does not occur in the species belonging to Ameira. At present, all species of Parapseudoleptomesochra do not share an apomorphy; careful morphological studies are required before a group of species sharing one or more apomorphies can be identified as belonging to Parapseudoleptomesochra. Thus, we agree with Lang (1965) to transfer $A$. trisetosa to the genus Parapseudoleptomesochra, the type species of the genus Parapseudoleptomesochra.

Parapseudoleptomesochra phayaoensis sp.n. shares a number of elements on P2-P3 Exp-3 and P2 Enp-3 with $P$. italica Pesce et Petkovski, 1980 from Italy (Table 1). However, $P$. phayaoensis sp.n. is distinguished from $P$. italica by several morphological features of the female. The chaetotaxy of P1-P4 Enp-3 can separate the females of both species. $P$. phayaoensis sp.n. possesses two apical setae and two outer spines on the P1 Exp-3, while $P$. italica has two apical setae and three outer spines. The P1 Enp-1 of P. phayaoensis sp.n. is approximately 3 times as long as wide, which is longer than the P1 Exp-1-2, while that of $P$. italica is shorter than the P1 Exp-1-2. The inner seta on P1 Exp-2 of P. phayaoensis sp.n. is longer than the segment, while that on P1 Exp2 of $P$. italica is about as long as the segment. The length of P2-P4 Enp-3 in the new species is about two times as long as wide, but for $P$. italica it is more than three times as long as wide. The P4 Enp-3 is armed with one inner pinnate seta and two apical pinnate setae in $P$. phayaoensis sp.n. versus two subapical inner setae and two subapical outer spines in $P$. italica.

The female P5 baseoendopod in P. phayaoensis sp.n. is only armed with 1 outer seta (=basal seta) versus five endopodal setae and one basal seta in P. italica. The female P5 Exp in $P$. phayaoensis sp.n. bears three setae versus six setae in $P$. italica. Similarly, the male P5 baseoendopod in $P$. phayaoensis sp.n. possesses 1 seta, while that in $P$. italica bears three spines. The male P5 Exp is armed with three setae in P. phayaoensis sp.n. versus five setae in $P$. italica. The comparisons of characters between $P$. phayaoensis sp.n. and $P$. italica are presented in Table 1. Furthermore, another feature that distinguishes the new species is the length of the inner accessories seta (seta VI) on

Table 1. Comparisons of morphological characters of Parapseudoleptomesochra phayaoensis sp.n. and $P$. italica.

Таблица 1. Сравнение морфологических признаков Parapseudoleptomesochra phayaoensis sp.n. и $P$. italica.

\begin{tabular}{lcc}
\hline \multicolumn{1}{c}{ Characters (female only) } & P.phayaoensis sp.n. & P. italica \\
\hline Inner seta on Exp-2 P1 & Longer than & As long as \\
& segment & 5 \\
Number of elements on P1 Exp-3 & 4 & 5 \\
Number of elements on P2-P3 Exp-3 & 5 & Shorter than P1 Exp-1-2 \\
Length of Enp-1 P1 & Longer than P1 Exp-1-2 & 3 \\
Number of elements on P1 Enp-3 & 3 & 3 on P2 and 4 on P3 \\
Number of elements on P2-P3 Enp-3 & 3 on both & 4 \\
Number of elements on P4 Enp-3 & 3 & $6: 5$ \\
$\begin{array}{l}\text { Number of setae or spines on P5 } \\
\text { (Exp:endopod) }\end{array}$ & $3: 0$ & \\
\hline
\end{tabular}


the caudal ramus is less than 1.5 times as long as dorsal seta (seta VII), while the condition in $P$. italica it is less than 3 times as long as the dorsal seta (seta VII).

Additionally, P. phayaoensis sp.n. is similar to $P$. hellenica Pesce, 1981 from Greece and $P$. attirei Dumont, 1984 from Sudan by the armature formula of P2-P4 Exp-3 of the females with 5, 5 and 6 elements, respectively.

However, the new species differs from $P$. hellenica in the following features: (1) the P1 Exp-3 of $P$. phayaoensis sp.n. is armed with four elements, while that in $P$. hellenica is armed with five elements, (2) the P4 Exp-3 $P$. phayaoensis sp.n. is armed with three elements, while that in $P$. hellenica is armed with four elements, (3) the length of caudal rami in $P$. hellenica is 1.7-1.9 times as long as wide, while that in $P$. phayaoensis sp.n. is 1.2 times as long as wide ( $\mathrm{n}=5)$, and (4) the armature of caudal rami in $P$. hellenica is composed of six elements, while that in the new species comprises seven elements.

ECOLOGY ANDDISTRIBUTION. Parapseudoleptomesochra phayaoensis sp.n. is found only in tiny freshwater pools filled mainly with dripping water from the roof of Chom Sin cave. There are no other subterranean water habitats inside this cave. The cave has one entrance, with a single horizontal gallery, and a permanent absence of light. The new species co-occurs with two cave-dwelling cyclopoid copepods viz., Thermocyclops thailandensis Karanovic, Koomput et Sanoamuang, 2017 and T. parahastatus Karanovic, Koomput et Sanoamuang, 2017. However, a putative closely related species, $P$. italica, was found in fresh and slightly brackish subterranean waters (anchialine and phreatic habitats) (Pesce, Petkovski, 1980). The family Ameiridae is of marine origin, but some ameirids were reported in both marine and fresh waters, particularly in subterranean environments. Moreover, P. phayaoensis sp.n. is considered to be a true stygobiont species by having the following morphological characteristics; the absence of a naupliar eye, a worm-like and cylindrical body, short antennules and antenna, armature reduction on baseoendopod of P5 (the new species has only one outer seta but others have 2-7) and a divergent caudal ramus (Pesce, Petkovski, 1980; Pesce, 1981; Dumont, 1984; Rouch, 1986; Mielke, 1995; Karanovic, 2004; Karanovic, 2006). In addition, the new species was collected from an epikarst habitat which is a natural pool filled by dripping water from the cave ceiling, and not connected to any surface water, which also supports the hypothesis of a true stygobiont species.

Acknowledgements. This research was supported by Center of Excellence on Biodiversity, Office of Higher Education Commission, Thailand (Project BDC-PG4-160020) and Graduate School of Khon Kaen University. We thank Prof. Tomislav Karanovic for identifying the samples and taking the SEM photos, Ms. Prapatsorn Dabseepai for assistance in the field, and Dr. Jesper Knijnenburg for the English corrections. The authors wish to thank Prof. Frank Ferrari for his constructive comments and suggestions.

\section{References}

Brady G.S. 1880. A monograph of the free and semiparasitic Copepoda of the British Islands // Ray Society, London Publ. Vol.2. P.1-182.

Boeck A. 1865. Oversigt over de ved Norges Kyster jagttagne Copepoder henhorende til Calanidernes, Cyclopidernes og Harpactidernes Familier // Forhandlinger i Videnskabs-Selskabet i Christiania. Vol.1864. P.226-282.

Boonyanusith C., Sanoamuang L., Brancelj A. 2018. A new genus and two new species of cave-dwelling cyclopoids (Crustacea, Copepoda) from the epikarst zone of Thailand and up-to-date keys to genera and subgenera of the Bryocyclops and Microcyclops groups // European Journal of Taxonomy. Vol.431. P.1-30.

Boxshall G.A., Defaye D. 2008. Global diversity of copepods (Crustacea: Copepoda) in freshwater // Hydrobiologia. Vol.595. P.195-207.

Boxshall G.A., Halsey S.H. 2004. An introduction to copepod diversity. London: The Ray Society Publ. 421 p.

Brancelj A. 2005. Hadodiaptomus dumonti n. gen., n. sp., a new freshwater stygobitic calanoid (Crustacea: Copepoda: Calanoida) from Vietnam (South Asia) and a new member of the subfamily Speodiaptominae Borutzky, 1962 // Hydrobiologia. Vol.534. No.1-3. P. 57-70.

Brancelj A., Watiroyram S., Sanoamuang L. 2010. The first record of cave-dwelling Copepoda from Thailand and description of a new species: Elaphoidella namnaoensis, sp. n. (Copepoda, Harpacticoida) // Crustaceana. Vol.83. P.779-793. 
Brancelj A., Boonyanusith C., Watiroyram S., Sanoamuang L. 2013. The groundwater-dwelling fauna of South East Asia // J. Limnol. Vol.72. (s2). P.327-344.

Chappuis P.A. 1929. Révision du genre Canthocamptus Westwood (Note préliminaire) // Buletinul Societatii de Stiinte din Cluj. Vol.4. No.2. P.41-50.

Dumont H.J. 1984. Parapseudoleptomesochra attire sp. n., a new species of Nitocrella from Nubia (Copepoda, Harpacticoida)// Hydrobiologia. Vol.110. P.177-180.

Cottarelli V., Bruno M.C., Berera R. 2010. First record of Parastenocarididae from Thailand and description of a new genus (Copepoda: Harpacticoida) // J. Crust. Biol. Vol.30. P.478-494.

Daday E.V. 1903. Die Schwarmbildung pelagischer Thiere // Zool. Anz. Vol.18. P.168-172.

Fosshagen A., Iliffe T.M. 1989. Boholina, a new genus (Copepoda: Calanoida) with two new species from an anchialine cave in the Philippines // Sarsia. Vol.74. No.3. P.201-208.

Huys R., Boxshall G.A. 1991. Copepod evolution. London: The Ray Society Publ. 468 p.

Jakobi H. 1972. Trends (Enp. P4) innerhalb der Parastenocarididen (Copepoda Harpacticoidea) // Crustaceana. Vol.22. P.127-146.

Karanovic T. 2004. Subterranean copepods (Crustacea, Copepoda) from arid Western Australia // Crustaceana Monograph. Brill: Leiden Publ. 1-366.

Karanovic T. 2006. Subterranean copepods (Crustacea, Copepoda) from the Pilbara region in Western Australia // Rec. Wes. Aus. Mus. Vol.70. P.1-239.

Karanovic T., Cho J.L. 2012. Three new ameirid harpacticoids from Korea and first record of Proameira simplex (Crustacea: Copepoda: Ameiridae) // Zootaxa. Vol.3368. P.91-127.

Karanovic T., Koomput K., Sanoamuang L. 2017. Two new Thermocyclops species (Copepoda, Cyclopoida) from Thailand, with notes on the phylogeny genus inferred from 18S and ITS sequences // Zool. Anz. Vol.269. P.26-47.

Kessler E. 1913. Parastenocaris brevipes nov. gen. et nov. spec., ein neuer Süsswasserharpacticide // Zool. Anz. Bd.42. H.11. S.514-520.

Kiefer F. 1927. Versuch eines Systems der Cyclopiden // Zool. Anz. Bd.73. S.302-308.

Krishnaswamy S. 1957. Two new psammophilous copepods from Madras // Zool. Anz. Vol.159. No.9-10. P.230-235.

Kunz H. 1975. Copepoda Harpacticoidea aus dem Litoral des slidlichen Afrika // Kiel. Meeresforsch. Bd.31. S. $179-212$.

Lang K. 1965. Copepoda Harpacticoida from the Californian Pacific coast // Kungl. Svenska Vetenskapsak. Handl. Bd.10. P.1-566.

MrázekA. 1893. Beitrag zur Kenntis der Harpacticidenfauna des Süsswassers // Zool. Jahrb., Abt. Syst. Oekol. Geogr. Tiere. Bd.7. H.1. S.89-130.

Mielke W. 1995. Interstitial copepods (Crustacea) from the Caribbean coast of Venezuela // Microfauna Mar. Vol.10. P.41-65.

Monard A. 1927. Synopsis universalis generum harpacticoiddarum // Zool. Jahrb., Abt. Syst. Oekol. Geogr. Tiere. Bd.54. S.139-176.

Pesce G.L. 1981. Some harpacticoids from subterranean waters of Greece (Crustacea: Copepoda) // Ital. J. Zool. Vol.48. P.263-276.

Pesce G.L., Petkovski T.K. 1980. Parapseudoleptomesochra italica $\mathrm{n}$. sp., a new harpacticoid from subterranean waters of Italy (Crustacea, Copepoda, Ameiridae) // Fragm. Balc. Vol.15. No.247. P.33-42.

Pesce G.L. 2016 Copepod Web Portal. Available from: http://www.luciopesce.net/copepods (accessed in May 2019)

Petkovski T.K. 1957. VI Beitrag zur Kenntnis der Grundwasser Copepoden unserer Meereskuste // Izdanija. Vol.8. No.1. S.1-16.

Petkovski T.K. 1976. Drei neue Nitocrella-Arten von Kuba, zugleich eine Revision des Genus Nitocrella Chappuis (s. restr.) (Crustacea, Copepoda, Ameiridae) // Acta Musei Macedonici Scientiarum Naturalium. Vol.15(1). No.126. S.1-26.

Rao G.C. 1972. Some new interstitial harpacticoid copepods from Andhra coast, India // Cah. Biol. Mar. Vol.13. No.3. P.305-319.

Rouch R. 1986. Quelques nouvelles Parapseudoleptomesochra Lang, 1965 (Harpacticoidea, Ameiridae) des eaux souterraines du sud de l'Espagne // Stygologia. Vol.2. P.217-253 [in French, with English summary].

Walter T.C.; Boxshall G.A. 2020. World of Copepods database. Parapseudoleptomesochra Lang, 1965. Accessed at: http://marinespecies.org/copepoda/ aphia.? $\mathrm{p}=$ taxdetails\&id $=115200$ on $2020-11-06$

Watiroyram S. 2018a. Two new species of the genus Bryocyclops Kiefer, 1927 (Copepoda: Cyclopoida: Cyclopidae) from southern Thailand // Raffles Bull. Zool. Vol.66. P.149-169.

Watiroyram S. 2018b. Bryocyclops asetus sp. n. and the presence of Bryocyclops muscicola (Menzel, 1926) from Thailand (Crustacea, Copepoda, Cyclopoida, Cyclopidae) // ZooKeys. Vol.793. P.29-51.

Watiroyram S., Brancelj A. 2016. A new species of the genus Elaphoidella Chappuis (Copepoda, Harpacticoida) from a cave in the south of Thailand // Crustaceana. Vol.89. No.4. P.459-476.

Watiroyram S., Brancelj A., Sanoamuang L. 2012. A new Bryocyclops Kiefer (Crustacea: Copepoda: Cyclopoida) from karstic caves in Thailand // Raffles Bull. Zool. Vol.60. No.1. P.11-21.

Watiroyram S., Brancelj A., Sanoamuang L. 2015a. Two new species of Elaphoidella (Crustacea: Copepoda: Harpacticoida) with comments on geographical distribution and ecology of harpacticoids from caves in Thailand // Zootaxa. Vol.3919. No.1. P.81-99.

Watiroyram S., Brancelj A., Sanoamuang L. 2015b. A new cave-dwelling copepod from northeastern Thailand (Cyclopoida: Cyclopidae)//Raffles Bull. Zool. Vol.63. P.426-437.

Watiroyram S., Sanoamuang L., Brancelj A. 2017. Two new species of Elaphoidella (Copepoda, Harpacticoida) from caves in southern Thailand and a key to the species of Southeast Asia // Zootaxa. Vol.4282. No.3. P.501-525.

Wells J.B.J. 2007. An annotated checklist and keys to the species of Copepoda Harpacticoida (Crustacea) // Zootaxa. Vol.1568. P.1-872.

Responsible editors V.N. Ivanenko and Frank Ferrari 